University of South Florida

DIGITAL COMMONS

Digital Commons @ University of

@ UNIVERSITY OF SOUTH FLORIDA

South Florida

$9-29-2006$

\title{
Subcentennial-Scale Climatic and Hydrologic Variability in the Gulf of Mexico During the Early Holocene
}

Jenna M. LoDico

University of South Florida

Benjamin P. Flower

University of South Florida, bflower@marine.usf.edu

Terrence M. Quinn

University of South Florida, quinn@marine.usf.edu

Follow this and additional works at: https://digitalcommons.usf.edu/msc_facpub

Part of the Marine Biology Commons

\section{Scholar Commons Citation}

LoDico, Jenna M.; Flower, Benjamin P.; and Quinn, Terrence M., "Subcentennial-Scale Climatic and Hydrologic Variability in the Gulf of Mexico During the Early Holocene" (2006). Marine Science Faculty Publications. 26.

https://digitalcommons.usf.edu/msc_facpub/26

This Article is brought to you for free and open access by the College of Marine Science at Digital Commons @ University of South Florida. It has been accepted for inclusion in Marine Science Faculty Publications by an authorized administrator of Digital Commons @ University of South Florida. For more information, please contact digitalcommons@usf.edu. 


\title{
Subcentennial-scale climatic and hydrologic variability in the Gulf of Mexico during the early Holocene
}

\author{
Jenna M. LoDico, ${ }^{1}$ Benjamin P. Flower, ${ }^{1}$ and Terrence M. Quinn ${ }^{1}$ \\ Received 11 November 2005; revised 20 April 2006; accepted 3 May 2006; published 29 September 2006.
}

[1] An early Holocene record from the Gulf of Mexico (GOM) reveals climatic and hydrologic changes during the interval from 10.5 to 7 thousand calendar years before present from paired analyses of $\mathrm{Mg} / \mathrm{Ca}$ and $\delta^{18} \mathrm{O}$ on foraminiferal calcite. The sea surface temperature record based on foraminiferal $\mathrm{Mg} / \mathrm{Ca}$ contains six oscillations and an overall $\sim 1.5^{\circ} \mathrm{C}$ warming that appears to be similar to the September-March insolation difference. The $\delta^{18} \mathrm{O}$ of seawater in the GOM $\left(\delta^{18} \mathrm{O}_{\mathrm{GOM}}\right)$ record contains six oscillations, including a $-0.8 \%$ excursion that may be associated with the " 8.2 ka climate event" or a broader climate anomaly. Faunal census records from three GOM cores exhibit similar changes, suggesting subcentennial-scale variability in the incursions of Caribbean waters into the GOM. Overall, our results provide evidence that the subtropics were characterized by decadal- to centennial-scale climatic and hydrologic variability during the early Holocene.

Citation: LoDico, J. M., B. P. Flower, and T. M. Quinn (2006), Subcentennial-scale climatic and hydrologic variability in the Gulf of Mexico during the early Holocene, Paleoceanography, 21, PA3015, doi:10.1029/2005PA001243.

\section{Introduction}

[2] The tropical and subtropical regions are responsible for transporting heat to the higher latitudes and play an important role in climate [Bigg, 2003]. Numerous paleoclimate reconstructions and models suggest that the tropical and the subtropical Atlantic experienced warmer conditions and greater moisture availability during the early Holocene, 10.5-7 thousands of years before present $(\mathrm{ka})$ compared to modern day. Ostracod $\delta^{18} \mathrm{O}$ records from Lake Miragoane, Haiti, suggest decreased evaporation-precipitation (E-P) during this time period [Hodell et al., 1991]. In the Cariaco Basin, increased percentage titanium (Ti) and percentage iron $(\mathrm{Fe})$, which are proxies for continental runoff, suggest decreased E-P in tropical South America [Haug et al., 2001]. Faunal assemblage records from the Gulf of Mexico (GOM) during the early Holocene indicate increased transport of Caribbean waters into the GOM and warmer than present winter sea surface temperatures (SST) [Kennett et al., 1985; Poore et al., 2003]. An alluvial record of sediments from central Texas suggests a period of maximum precipitation during the early Holocene [Nordt et al., 1994]. Last, various climate records from the tropical and subtropical Atlantic Ocean suggest the early Holocene was a warm period with substantial decadal- to centennial-scale variability [Peterson et al., 2000; Haug et al., 2001; Poore et al., 2003; Lea et al., 2003], although the geographic and temporal coherence of these low-latitude climate variations remains unclear.

[3] The early Holocene was a transitional time period with respect to Earth's orbital parameters. After a maximum in summer insolation and a minimum in winter insolation at

\footnotetext{
${ }^{1}$ College of Marine Science, University of South Florida, St. Petersburg, Florida, USA.
}

Copyright 2006 by the American Geophysical Union. 0883-8305/06/2005PA001243 $\sim 12 \mathrm{ka}$, the seasonal contrast in the Northern Hemisphere slowly reduced during the remainder of the Holocene. The "Holocene Climatic Optimum" or "Hypsithermal" following the maximum in insolation is generally defined as a warm period during the interval 10 to $5 \mathrm{ka}$, but the timing and the extent of warming depends on the region in consideration [Ruddiman, 2001]. Some components of the climate system, such as the Asian monsoons, appear to respond relatively quickly to orbital insolation changes [Kutzbach and Gallimore, 1988]. On the other hand, terrestrial conditions in North America may have responded more slowly to the orbital forcing because the Laurentide Ice Sheet influenced regional temperatures until $\sim 9 \mathrm{ka}$ [Mitchell et al., 1988]. Did the tropical and subtropical Atlantic climate system significantly affect North American climates during the early to mid-Holocene?

[4] In the high northern latitudes, an abrupt cooling during the early Holocene known as the " 8.2 ka event" disrupted normally warm temperatures. From 8.3 to $8.1 \mathrm{ka}$ temperatures dropped $4^{\circ}-8^{\circ} \mathrm{C}$ in central Greenland [Alley et al., 1997] possibly resulting from the reduction, or shut down, of thermohaline circulation related to the draining of proglacial Lake Agassiz [Barber et al., 1999; Teller et al., 2002]. Evidence of temperature changes, atmospheric circulation changes, and hydrologic changes associated with the $8.2 \mathrm{ka}$ event exists in proxy records from sites in the North Atlantic Ocean, North Africa, and North America [Klitgaard-Kristensen et al., 1998; von Grafenstein et al., 1998; Tinner and Lotter, 2001; Dean et al., 2002; Lachniet et al., 2004]. Regional climate responses include a weaker South American monsoon [Lachniet et al., 2004], enhanced trade winds and drier conditions over the Cariaco Basin [Hughen et al., 1996], and a reorganization of atmospheric circulation over Central North America [Dean et al., 2002]. A recent synthesis suggests that many climate proxies that indicate anomalies occurring around $8.2 \mathrm{ka}$ may be reflecting a broader climate anomaly rather than one sharp event 


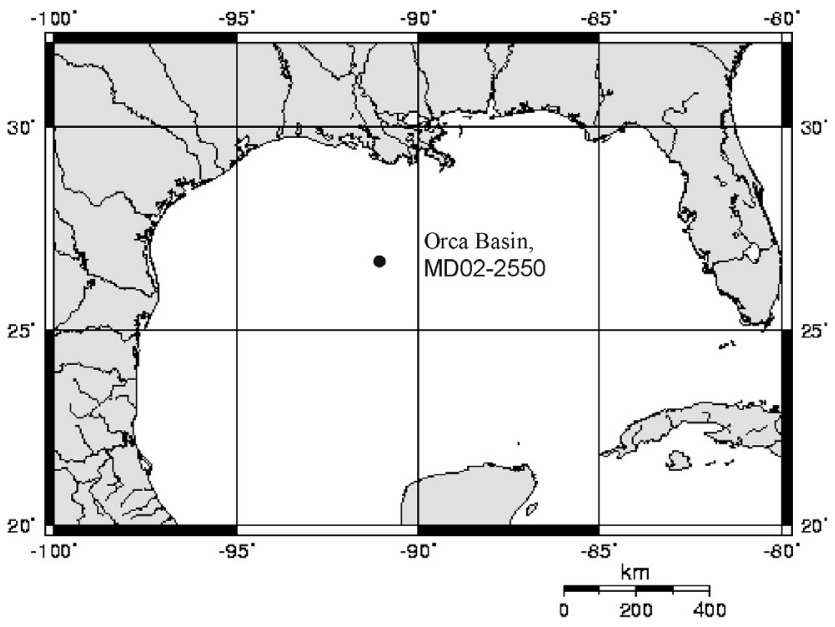

Figure 1. Map of the Gulf of Mexico (GOM) showing location of core MD02-2550 $\left(26^{\circ} 56.77^{\prime} \mathrm{N}, 91^{\circ} 20.74^{\prime} \mathrm{W}\right.$ at $2248 \mathrm{~m}$ water depth in Orca Basin).

[Rohling and Pälike, 2005]. Many of these proxy records indicate a long-term cooling beginning at $8.6 \mathrm{ka}$ and spanning between 400 and 600 years with the seasonal bias of the record being of great importance.

[5] Here we present high-resolution, early Holocene paleoclimate records from the Orca Basin, GOM from 10.5 to $7 \mathrm{ka}$. Paired $\delta^{18} \mathrm{O}$ and $\mathrm{Mg} / \mathrm{Ca}$ data on Globigerinoides ruber provide derived SST and $\delta^{18} \mathrm{O}_{\text {seawater }}\left(\delta^{18} \mathrm{O}_{\mathrm{sw}}\right)$ records. These records, as well as faunal assemblage records, indicate substantial decadal- to centennial-scale climatic and hydrologic variability, including a substantial salinity decrease and major shift in the biotic community at $\sim 8.6$ to $8.3 \mathrm{ka}$.

\section{Site Location and Methods}

[6] The Western Hemisphere Warm Pool (WHWP), which encompasses the Caribbean and the GOM, develops in the late summer with $\mathrm{SST}$ reaching $>28.5^{\circ} \mathrm{C}$. The WHWP provides moisture to the North American continent as far north as Canada [Wang and Enfield, 2001] and to the North American Monsoon System, which influences northern Mexico and the American Southwest [Metcalfe et al., 2000]. The Orca Basin (Figure 1), which is situated $\sim 300 \mathrm{~km}$ from the present Louisiana coast, is ideally located to record not only regional climate changes but the influence of freshwater from the Mississippi River system as well. The Orca Basin is advantageous for highresolution Holocene paleoclimatology because of high sedimentation rates (approximately $30 \mathrm{~cm} / 1000 \mathrm{yr}$ ) and a brine layer (salinity $>250$ ) overlying the sediment that preserves sedimentary laminations throughout the Holocene [Leventer et al., 1983]. The continuous presence of pteropods tests throughout the Holocene portion of the sediment core indicates minimal dissolution of carbonate material.

[7] In July 2002, core MD02-2550 (9.09 m) was recovered from Orca Basin $\left(26^{\circ} 56.78 \mathrm{~N} 91^{\circ} 21.75 \mathrm{~W}\right)$ at a water depth of $2248 \mathrm{~m}$. For this study, section 2 of core MD02-2550 was sliced continuously at $0.5 \mathrm{~cm}$ intervals. Samples were wet sieved at $63 \mu \mathrm{m}$ and dried in a $\sim 50^{\circ} \mathrm{C}$ oven. The samples were split using a microsplitter with one half designated for faunal assemblage analysis and the other half designated for geochemical analysis. The first split was sieved at the $>150 \mu \mathrm{m}$ size fraction and further split to obtain approximately 300 individual foraminifers for the faunal assemblage census. Planktonic foraminifers in the census were identified to species and counted; the relative frequency of each planktonic foraminifer species was expressed as percent of the total planktonic foraminiferal assemblage.

[8] From the geochemical split, sets of 70 G. ruber (white variety) were picked from $250-355 \mu \mathrm{m}$ size fraction, gently crushed, and split into aliquots for analysis of stable isotope and minor elements $(\mathrm{Mg} / \mathrm{Ca})$. Approximately $80 \mu \mathrm{g}$ were sonicated in methanol and analyzed on a Finnigan MAT Delta Plus XL light stable isotope ratio mass spectrometer (SIRMS) at the College of Marine Science, University of South Florida. The $\delta^{18} \mathrm{O}_{\text {calcite }}\left(\delta^{18} \mathrm{O}_{\mathrm{c}}\right)$ data (Figure 2) are reported on the VPDB scale calibrated with standard NBS-19. External precision of this instrument based on

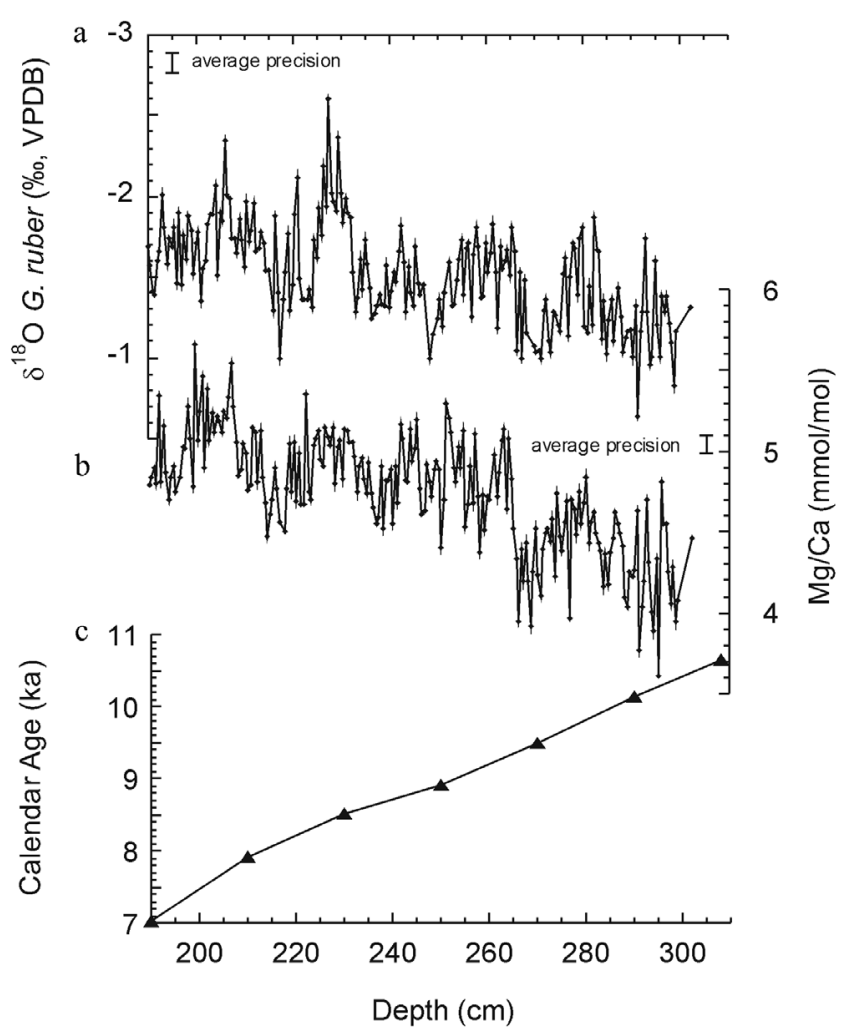

Figure 2. Paired $\delta^{18} \mathrm{O}$ and $\mathrm{Mg} / \mathrm{Ca}$ data based on G. ruber (white variety, 250-355 $\mu \mathrm{m}$ ) and age model for core MD02-2550. (a) Raw $\delta^{18} \mathrm{O}$, (b) raw $\mathrm{Mg} / \mathrm{Ca}$, and (c) age model based on seven accelerator mass spectrometer ${ }^{14} \mathrm{C}$ dates on G. ruber (white and pink varieties) calibrated to calendar years using CALIB 5.0 (http://radiocarbon.pa.qub. ac.uk) (Table 1). 
Table 1. The ${ }^{14} \mathrm{C}$ Accelerator Mass Spectrometer Dates From Core MD02-2550 ${ }^{\mathrm{a}}$

\begin{tabular}{cccccc}
\hline CAMS & $\begin{array}{c}\text { Depth in } \\
\text { Core, cm }\end{array}$ & $\begin{array}{c}{ }^{14} \text { C AMS } \\
\text { Age, ka }\end{array}$ & $\begin{array}{c}{ }^{14} \text { C Error, } \\
\pm \text { year }\end{array}$ & $\begin{array}{c}\text { Calibrated } \\
\text { Age, }{ }^{b} \text { ka }\end{array}$ & $\begin{array}{c}\text { Calibrated } \\
\text { Error, } \pm \text { year }\end{array}$ \\
\hline 100670 & $190-190.5$ & 6.110 & 35 & 7.02 & 64 \\
100671 & $210-210.5$ & 7.050 & 40 & 7.93 & 89 \\
100672 & $230-230.5$ & 7.650 & 35 & 8.50 & 90 \\
100673 & $250-250.5$ & 7.930 & 40 & 8.91 & 134 \\
100674 & $270.5-271$ & 8.415 & 40 & 9.48 & 66 \\
100675 & $290-290.5$ & 8.885 & 40 & 10.14 & 176 \\
100676 & $307.5-308$ & 9.390 & 40 & 10.64 & 125 \\
\hline
\end{tabular}

${ }^{\mathrm{a}}$ Definitions are AMS, accelerator mass spectrometer; and CAMS, Center for Accelerator Mass Spectrometry, Lawrence Livermore National Laboratory.

${ }^{\mathrm{b}}$ Dates are calibrated to calendar ages using CALIB 5.0 Radiocarbon Conversion Program (http://radiocarbon.pa.qub.ac.uk/calib/) [Stuiver et al., 1998].

$>1000$ standards run since July 2000 is $\pm 0.06 \%$ for $\delta^{13} \mathrm{C}$ and $\pm 0.09 \%$ for $\delta^{18} \mathrm{O}$.

[9] Approximately $300-500 \mu \mathrm{g}$ of material underwent an extensive cleaning process for $\mathrm{Mg} / \mathrm{Ca}$ analysis [Barker et al., 2003]. This process includes multiple water rinses, multiple methanol rinses, an oxidizing treatment and a weak acid leach. Foraminiferal $\mathrm{Mg} / \mathrm{Ca}$ (Figure 2) was analyzed on a Perkin Elmer 4300 DV Inductively Coupled Plasma Optical Emission Spectrometer (ICP-OES) at the College of Marine Science, University of South Florida. Analytical precision for $\mathrm{Mg} / \mathrm{Ca}$ is $\leq 0.4 \%$ root mean standard deviation $(1 \sigma)$. Samples were alternated with standards to account for instrument drift (following Schrag [1999]. SST values were determined using the Anand et al. [2003] calibration curve for $G$. ruber (white variety; $250-355 \mu \mathrm{m}$ ) which is as follows: $\mathrm{Mg} / \mathrm{Ca}=0.449 \exp (0.090 * \mathrm{SST})\left({ }^{\circ} \mathrm{C}\right)$. Average standard deviation based on $54 \%$ replicate analysis is $\pm 0.10 \mathrm{mmol} / \mathrm{mol}$ for $\mathrm{Mg} / \mathrm{Ca}$, which corresponds to $\pm 0.17^{\circ} \mathrm{C} ; 5 \%$ of replicated samples were determined to have been contaminated during the cleaning procedure and were omitted from the plots only (see supporting data). ${ }^{1}$

[10] The chronology for core MD02-2550 from 190 to $310 \mathrm{~cm}$ was based on seven accelerator mass spectrometer (AMS) ${ }^{14} \mathrm{C}$ dates from monospecific G. ruber (white and pink varieties) (Table 1 and Figure 2). AMS ${ }^{14} \mathrm{C}$ dates were determined at the Center for Accelerator Mass Spectrometer, Lawrence Livermore National Laboratory in Livermore, CA. Radiocarbon ages were corrected using a constant 400 year reservoir age, and then were calibrated to calendar years using the Calib5.0 [Stuiver et al., 1998] online conversion program (http://radiocarbon.pa.qub.ac.uk/calib) (Table 1). Core depth in centimeters was converted to calendar age by linear interpolation and yielded sedimentation rates of $30 \pm 16 \mathrm{~cm} / \mathrm{kyr}$, which gives an average sampling resolution of $\sim 20 \pm 10$ years during the early Holocene interval. AMS ${ }^{14} \mathrm{C}$ dates from the western $\mathrm{GOM}$ (core RC 12-10) [Poore et al., 2003] and the Pigmy Basin (MD02-2553) [Poore et al., 2004] were also calibrated to

\footnotetext{
html.

${ }^{1}$ Auxiliary materials are available at www.ncdc.noaa.gov/paleo/paleo.
}

calendar years in this contribution using the Calib5.0 online conversion program.

\section{SST Variability in the Early Holocene}

[11] The white variety of $G$. ruber is a tropical to subtropical, surface-dwelling species (upper $50 \mathrm{~m}$ ), which makes it ideal for recording SST [Bé and Hamlin, 1967; Hemleben et al., 1989]. At the present time there is no seasonal flux information for G. ruber from the GOM, but evidence from the Sargasso Sea suggests that the white variety of $G$. ruber is a suitable species to reflect the mean annual temperature [Deuser et al., 1981; Deuser, 1987; Deuser and Ross, 1989; Williams et al., 1981]. A core top value of $4.86 \mathrm{mmol} / \mathrm{mol} \mathrm{Mg} / \mathrm{Ca}$ based on the white variety of G. ruber corresponds to $26.5^{\circ} \mathrm{C}$, which is close to the present mean annual SST [Levitus, 2003].

[12] The mean Mg-SST value derived from G. ruber (white variety) from the $10.5-7 \mathrm{ka}$ interval (Figure 3) is $26.3^{\circ} \pm 0.17^{\circ} \mathrm{C}$ (Figure 3 ) and the SSTs range from $23.6^{\circ}$ to $28.1^{\circ} \mathrm{C}$, which is close to the present seasonal range in SST

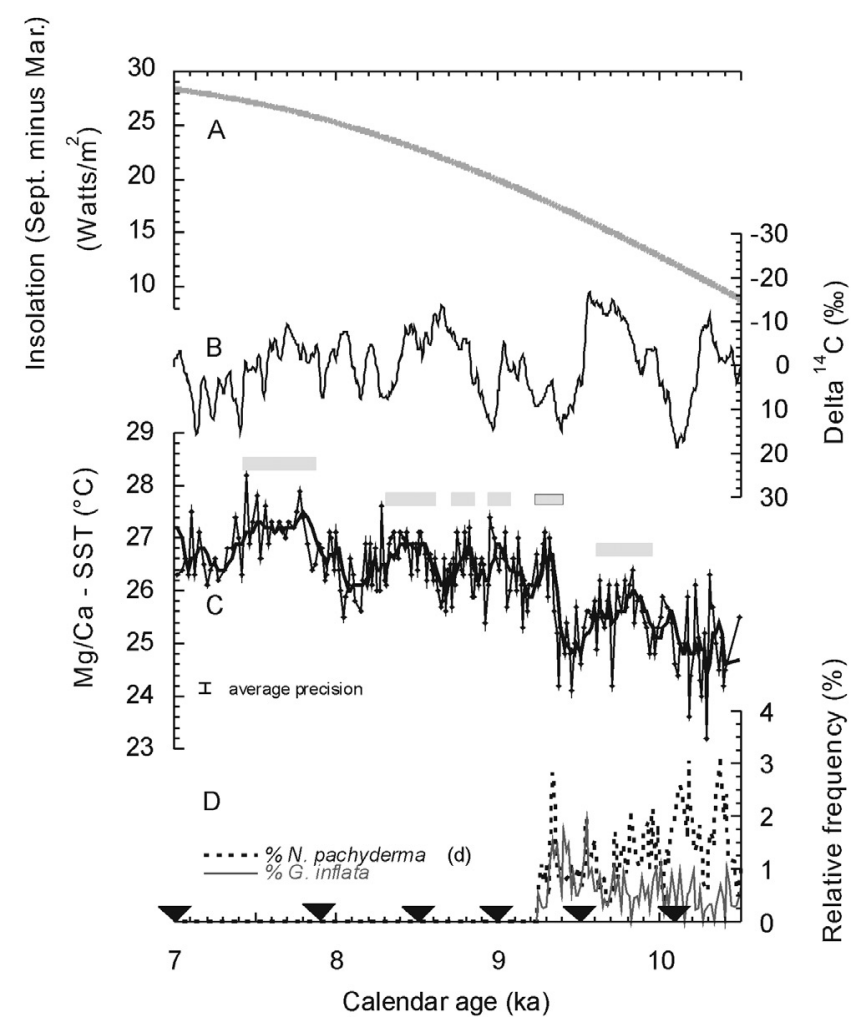

Figure 3. (a) Difference between September and March insolation at $27^{\circ} \mathrm{N}$ [Laskar, 1990]. (b) Delta ${ }^{14} \mathrm{C}$ record plotted on an inverted scale so increased solar output is up [Reimer et al., 2004]. (c) Orca Basin core MD02-2550 Mgderived SST based on G. ruber with five-point smooth fit. Horizontal shaded bars indicate periods of SST increases as defined in the text. (d) Relative frequency of cool-water foraminifer species $N$. pachyderma (dextral) and $G$. inflata. Inverted triangles indicate ages of six accelerator mass spectrometer ${ }^{14} \mathrm{C}$ dates for MD02-2550 calibrated to calendar years (Table 1). 
for the GOM $\left(23^{\circ}-29^{\circ} \mathrm{C}\right.$ [Levitus, 2003]). The SST record exhibits a gradual warming of $1.5^{\circ} \mathrm{C}$ from 10.5 to $7 \mathrm{ka}$. From 10.5 to $9.4 \mathrm{ka}, \mathrm{SSTs}$ averaged $25.5^{\circ} \mathrm{C}$, and varied by $1-2^{\circ} \mathrm{C}$. This cool interval is supported by faunal census data. Cool-water foraminifer species Neogloboquadrina pachyderma (dextral) and Globoconella inflata (Figure 3) are present in low abundance $(<3.5 \%)$ until $9.3 \mathrm{ka}$ when they disappear. These species exhibit significantly higher frequencies during the last glaciation [Kennett et al., 1985; Flower and Kennett, 1990, 1995]. From 9.4 to 8.0 ka, SST averaged $26.5^{\circ} \mathrm{C}$ and varied by $0.5-1.5^{\circ} \mathrm{C}$. From 8.0 to $7.0 \mathrm{ka}, \mathrm{SST}$ averaged $27^{\circ} \mathrm{C}$ and varied by $1.5^{\circ} \mathrm{C}$. Superimposed on the gradual warming is an abrupt increase of $1.5^{\circ} \mathrm{C}$ occurring from 9.4 to $9.3 \mathrm{ka}$.

[13] The trend of our $\mathrm{Mg} / \mathrm{Ca}-\mathrm{SST}$ record appears to be similar to precession controlled changes in seasonal insolation. Climate proxy records from the Yucatan Peninsula [Hodell et al., 1991] and the Cariaco Basin [Haug et al., 2001] exhibit a similar relation to regional insolation seasonality. During the early Holocene in the GOM, the insolation difference between September and March increased by nearly $20 \mathrm{~W} / \mathrm{m}^{2}$ [Laskar, 1990] (Figure 3a). The seasonal distribution of the white variety of G. ruber may have shifted during the early Holocene in response to warmer summers and cooler winters produced by enhanced seasonality in insolation. Although it may be present in the upper water column during the entire year and can withstand SST as low as $10^{\circ} \mathrm{C}, G$. ruber white variety shows optimum growth in the SST range of $24.2-29.7^{\circ} \mathrm{C}$ [Zaric et al., 2005]. Cooler winters may have increased the preference of $G$. ruber (white variety) to grow during the warmer summer months.

[14] Although our record ends at $7 \mathrm{ka}$, we appear to have captured part of the "Holocene Climatic Optimum" in the GOM. Our SST record reaches maximum warming between 8 and $7 \mathrm{ka}$. This is consistent with faunal census data from other Orca Basin cores [Kennett et al., 1985] and a western GOM core [Poore et al., 2003]. An increase in the warmwater species Globorotalia menardii and Pulleniatina obliquiloculata is documented in Orca Basin cores [Kennett et al., 1985] and western GOM cores [Poore et al., 2003] during the early Holocene suggesting the warmest SST by $7.5 \mathrm{ka}$. The faunal census data from MD02-2550 exhibit similar relative frequencies from 10.5 to $7 \mathrm{ka}$ in $G$. menardii and P. obliquiloculata [LoDico, 2006]. In addition, alkenone records from the Tobago Basin in the tropical Atlantic Ocean reach a modern SST of $28.5^{\circ} \mathrm{C}$ by $8 \mathrm{ka}$ indicative of an overall $1.5^{\circ} \mathrm{C}$ warming of SST during the early Holocene [Ruhlemann et al., 1999].

[15] Similarly, North American continental records suggest a warm period during the early Holocene with regional differences in moisture availability. Pollen records indicate maximum warming in the Great Plains of North America by 9 ka [Baker and Waln, 1985]. Vegetation records from eastern North America suggest warming [Bernabo and $W e b b, 1977]$, and the Elk Lake record from northwestern Minnesota trends toward warmer and more arid conditions from $8 \mathrm{ka}$ to present [Dean et al., 2002]. Records from the midwestern United States suggest a $2^{\circ} \mathrm{C}$ warming in mean annual temperatures during the early Holocene [Webb et al., 1983]. Pollen records from the southeastern United States document an increase in moisture availability [Webb et al., 1993].

[16] In contrast, some regional records from the lowlatitude Atlantic Ocean exhibit an early "Holocene Climatic Optimum" around $10 \mathrm{ka}$. SST records from Cariaco Basin, suggest maximum $\mathrm{SSTs}$ of $27^{\circ} \mathrm{C}$ from 11 to $8 \mathrm{ka}$ [Lea et al., 2003]. Records from the Caribbean Sea indicate a peak in SST reaching modern values of $28.5^{\circ} \mathrm{C}$ by $11 \mathrm{ka}$ [Schmidt et al., 2004]. Pollen records suggest that Mexico was cooler than present until $10.2 \mathrm{ka}$ and then the early Holocene warming began [Metcalfe et al., 2000], which is consistent with the Cariaco record. Overall, there is considerable evidence that continental North America and the GOM reached optimum temperatures around 9-7 ka, whereas lower-latitude records (except Tobago Basin) exhibit an earlier climatic optimum. It is possible that North America and GOM climates may have still been under the influence of the Laurentide Ice Sheet during the early Holocene, thus producing a delayed climate optimum [Mitchell et al., 1988].

[17] The warming trend in the GOM is punctuated by six distinct increases in temperature ranging from $0.5^{\circ}$ to $1^{\circ} \mathrm{C}$ and lasting between 100 to 500 years (horizontal shaded bars, Figure 3c) above the two local means. The SST record clearly has decadal to centennial-scale variability, and the comparison to the atmospheric $\Delta^{14} \mathrm{C}$ record (Figure $3 \mathrm{~b}$ ) [Reimer et al., 2004] is used to investigate a link between solar variability and climate. Five out of the six SST maximum appear to be associated with peaks in solar activity. However, the overall correlation between these two records is low $(\mathrm{r}=0.2)$. Therefore some of the variability in the $\mathrm{Mg} / \mathrm{Ca}-\mathrm{SST}$ record may be connected to solar variability, but other controls such as oceanic and or atmospheric circulation must have played a larger role.

\section{The $\delta^{18} \mathrm{O}_{\mathrm{GOM}}$ Variability in the Early Holocene}

[18] The $\delta^{18} \mathrm{O}_{\mathrm{c}}$ record based on G. ruber (Figure 2) is a function of temperature and the $\delta^{18} \mathrm{O}_{\mathrm{sw}}$ at the time of calcification, which in turn depends on ice volume and salinity. In order to isolate $\delta^{18} \mathrm{O}_{\mathrm{sw}}$, the temperature component was removed from the $\delta^{18} \mathrm{O}_{\mathrm{c}}$ values using the $\mathrm{Mg} / \mathrm{Ca}-$ SST estimates. The Bemis et al. [1998] Orbulina universa high-light equation $\left(\operatorname{SST}\left({ }^{\circ} \mathrm{C}\right)=14.9-4.8\left(\delta^{18} \mathrm{O}_{\mathrm{c}}-\delta^{18} \mathrm{O}_{\mathrm{sw}}\right)\right)$ was utilized because it is also appropriate for $G$. ruber [Thunell et al., 1999; Spero et al., 2003]. Adding 0.27\%o produces a $\delta^{18} \mathrm{O}_{\mathrm{sw}}$ record on the Vienna Standard Mean Ocean Water (VSMOW) scale. Propagation of error [Beers, 1957] including analytical error and combined errors in $\mathrm{Mg} /$ $\mathrm{Ca}-\mathrm{SST}$ and $\delta^{18} \mathrm{O}$ calibrations is $\pm 0.26 \%$. Last, we subtract contributions from global ice volume changes by using a sea level record [Fairbanks, 1989; Bard et al., 1996] to isolate a $\mathrm{GOM} \delta^{18} \mathrm{O}_{\mathrm{sw}}$ residual $\left(\delta^{18} \mathrm{O}_{\mathrm{GOM}}\right)$ (Figure $\left.4 \mathrm{a}\right)$. Sea level height was converted to the corresponding $\delta^{18} \mathrm{O}_{\mathrm{sw}}$ with the relationship of $0.083 \%$ per $10 \mathrm{~m}$ sea level change [Adkins and Schrag, 2001].

[19] The $\delta^{18} \mathrm{O}_{\mathrm{GOM}}$ record tracks changes in E-P processes in the GOM, as well as freshwater inputs from the Mississippi River system. Paired core top values of $\mathrm{Mg} / \mathrm{Ca}$ $\left(4.86 \mathrm{mmol} / \mathrm{mol} ; 26.5^{\circ} \mathrm{C} \mathrm{SST}\right)$ and $\delta^{18} \mathrm{O}_{\mathrm{c}}$ of $-1.55 \%$ yield a 


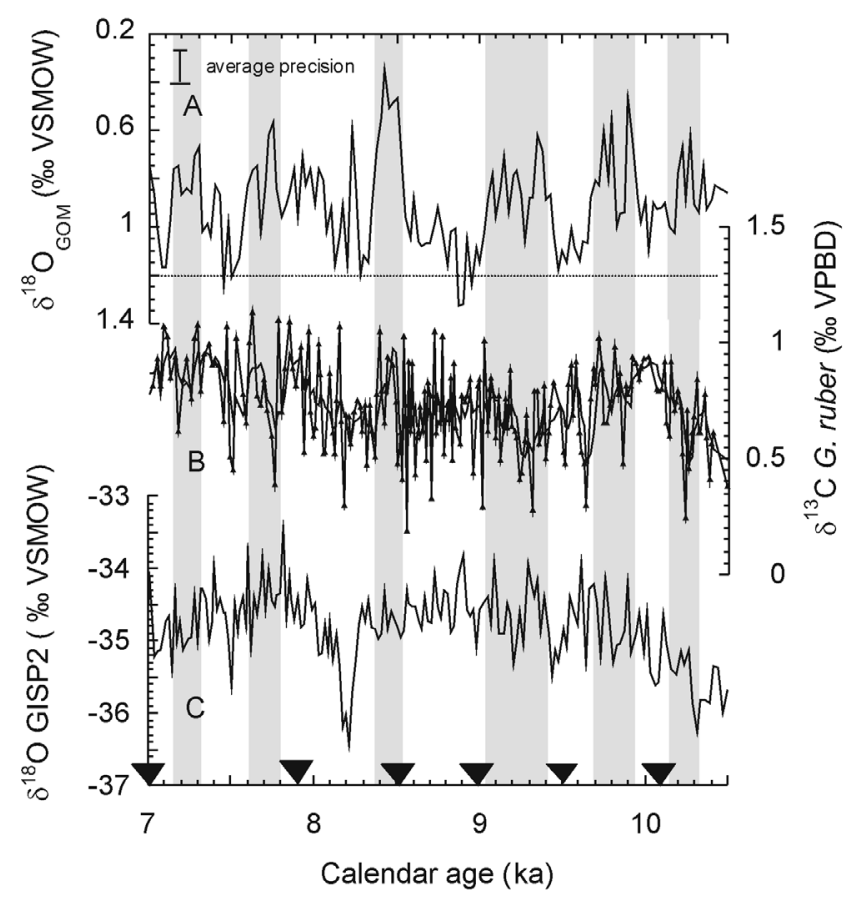

Figure 4. (a) The $\delta^{18} \mathrm{O}_{\mathrm{GOM}}$ calculated from paired analysis of $\delta^{18} \mathrm{O}_{G}$. ruber and $\mathrm{Mg} / \mathrm{Ca}-\mathrm{SST}$ and corrected for ice volume, with the modern $\delta^{18} \mathrm{O}_{\mathrm{GOM}}$ of $1.2 \%$ indicated by the dashed horizontal bar and the vertical shaded bars indicating negative excursions as defined in text. (b) Raw $\delta{ }^{13} C_{G}$. ruber with five-point smooth fit. (c) Greenland air temperature record based on Greenland Ice Sheet Project 2 (GISP2) $\delta^{18} \mathrm{O}$ data [Grootes et al., 1993]. Inverted triangles indicate ages of six accelerator mass spectrometer ${ }^{14} \mathrm{C}$ dates for MD022550, calibrated to calendar years (Table 1).

$\delta^{18} \mathrm{O}_{\mathrm{GOM}}$ of $1.16 \%$, which is in good agreement with the modern $\delta^{18} \mathrm{O}_{\mathrm{sw}}$ value of $1.2 \%$ in the GOM [Fairbanks et al., 1992]. The early Holocene $\delta^{18} \mathrm{O}_{\mathrm{GOM}}$ mean of $0.9 \%$ appears to be slightly lower than the modern seawater $\delta^{18} \mathrm{O}$ value of $1.2 \%$, suggesting lower mean salinity in the early Holocene (see section 5). Our $\delta^{18} \mathrm{O}_{\mathrm{GOM}}$ record contains six oscillations of $0.5 \%$ about the mean, each lasting between 300-600 years (vertical shaded bars, Figure 4a). These negative excursions suggest centennial-scale variations in $\delta^{18} \mathrm{O}_{\mathrm{GOM}}$ attributed to some combination of changing E-P processes and river input.

[20] In the $\delta^{18} \mathrm{O}_{\mathrm{GOM}}$ record, the largest negative pulse of almost $\sim 1 \%$ reaches a minimum of $\sim 0.4 \%$ at $8.4 \mathrm{ka}$, constrained by nine points from 8.6 to $8.3 \mathrm{ka}(7.6-7.4$ ${ }^{14} \mathrm{C} \mathrm{ka)}$. At face value, our data suggest a regional, lowsalinity anomaly that spanned $\sim 300$ years and preceded the 8.2 climate event known from Greenland air temperature (Figure 4c). Accordingly, our data are consistent with the finding that a broad, complex climate anomaly is observed from $\sim 8.6-8.0 \mathrm{ka}$ [Rohling and Pälike, 2005]. However, given the total uncertainty associated with calibration to calendar years it is possible that the GOM event is more closely associated with the $8.2 \mathrm{ka}$ event $\left(7.4-7.2{ }^{14} \mathrm{C} \mathrm{ka}\right)$ that is present in the Greenland air temperature record. Either way, our data suggest that the GOM was marked by an episode of greater moisture availability from approximately $8.6-8.3 \mathrm{ka}$.

[21] We also consider the possibility that glacial meltwater entered the GOM at this time. Geologic evidence indicates that following the Younger Dryas, the GOM drainage outlet for the Laurentide Ice Sheet was abandoned by $11 \mathrm{ka}$ [Teller et al., 2002; Fisher, 2003]. The Laurentide Ice Sheet retreated to the Hudson Bay region by $8.5 \mathrm{ka}$ [Clarke et al., 2003]. The freshwater from the proglacial Lake Agassiz is considered to have drained north into Hudson Bay at $8.47 \mathrm{ka}$ and geomorphic evidence precludes a southern routing of this freshwater [Barber et al., 1999]. Given the age uncertainties, this pulse may be related to a southern freshwater pulse in the Great Lakes system from 8.9 to $8.5 \mathrm{ka}$ documented by Moore et al. [2000]. Therefore, at $8.4 \mathrm{ka}$ we cannot rule out the possibility that the largest negative pulse in the $\delta^{18} \mathrm{O}_{\mathrm{GOM}}$ record reflects, in part, freshwater from the Laurentide Ice Sheet. Meltwater with a $\delta^{18} \mathrm{O}$ composition close to the Laurentide Ice Sheet would require minimal salinity changes in the GOM (see section 5).

[22] Other subtropical Atlantic Ocean climate records suggest significant changes in moisture availability in the early Holocene. The \% Ti record from the Cariaco Basin is interpreted to be a summer-dominated proxy of rainfallinduced runoff from rivers in Venezuela and can be used to infer changes in hydrologic balance in subtropical South America [Haug et al., 2001]. The Cariaco Basin record exhibits a maximum in \% Ti during the early Holocene, suggesting overall wetter conditions between 10.5 and $5.4 \mathrm{ka}$, which is consistent with a more northerly position of the ITCZ. Superimposed on this trend are many highfrequency excursions in percentage $\mathrm{Ti}$. The percentage of $\mathrm{Ti}$ record indicates decreasing amounts of terrestrial runoff beginning around $8.6 \mathrm{ka}$, with two individual minima occurring at 8.4 and $8.2 \mathrm{ka}$. In contrast, the Cariaco gray scale record, a winter-dominated proxy for wind-driven productivity implies a sharp increase from 8.3 to $8.1 \mathrm{ka}$ [Peterson et al., 2000]. Taken together, these records support the inference of an external summer-dominated climate anomaly from $\sim 8.6-8.2 \mathrm{ka}$, with a sharp winter-dominated climate anomaly from $\sim 8.3-8.1 \mathrm{ka}$ [Rohling and Pälike, 2005].

[23] Overall, the modest agreement between our records and regional records of ITCZ variability suggests additional controls on surface ocean variability in the GOM area. The episodic decreases in $\delta^{18} \mathrm{O}_{\mathrm{GOM}}$ may also be indicative of large-scale hydrologic variability in the Mississippi River system. The negative excursions may be attributed to some combination of increased flooding from Mississippi River system and net changes in E-P. Changing seasonal insolation will change the strength of the monsoons [Kutzbach and Gallimore, 1988]. We speculate that increased seasonality of insolation enhanced North American Monsoon variability and associated rainfall in the GOM region, including the Mississippi River system. Large flooding can occur in the Upper Mississippi River Valley when strong meridional patterns develop between moist warm air masses from the GOM and the jet stream [Knox, 2000]. During the early Holocene, episodic northward shifts of the ITCZ compared to present day may have enhanced precip- 


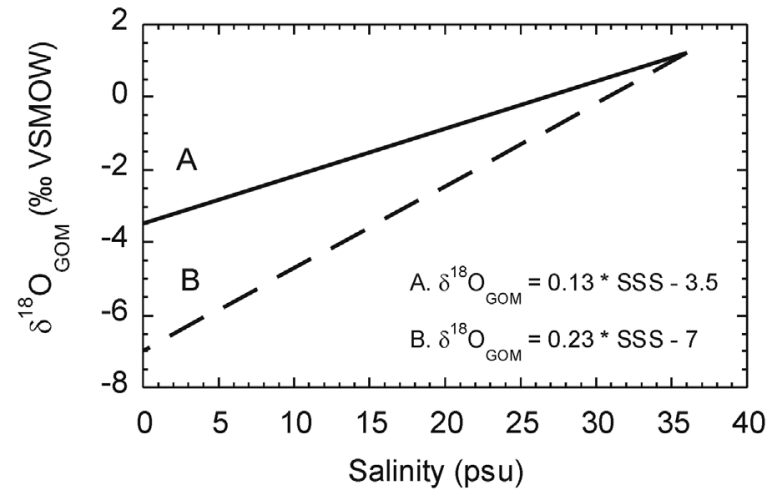

Figure 5. Mixing model for GOM used for estimated salinities determined from modern relationship between salinity and $\delta^{18} \mathrm{O}_{\mathrm{Sw}}$. Modern precipitation end-member, $-3.5 \%$, is labeled A [Bowen and Revenaugh, 2003], Modern Mississippi River end-member, $-7 \%$, is labeled B [Ortner et al., 1995]. Note that the lower end-member requires smaller salinity changes in the GOM.

itation over the GOM and the North American monsoon region.

\section{The $\delta^{13} \mathrm{C}$ Record}

[24] The $\delta^{13} \mathrm{C}_{\text {DIC }}$ in GOM surface waters is controlled by Mississippi River water input and primary production. Mississippi River water is depleted in ${ }^{13} \mathrm{C}$ (modern $\delta^{13} \mathrm{C}=$ -11 to $-5 \%$ ) mainly because of ${ }^{13} \mathrm{C}$-depleted soils [Tan, 1989]. Primary production leaves the surface waters more enriched in $\delta^{13} \mathrm{C}(\sim 2 \%)$ because of the preferential sequestering of ${ }^{12} \mathrm{C}$ by photoautotrophs. Accordingly, shifts in the G. ruber $\delta^{13} \mathrm{C}$ result from the interplay between Mississippi River input and primary production. Previous work suggests that a positive relationship between G. ruber $\delta^{18} \mathrm{O}$ and $\delta^{13} \mathrm{C}$ indicates episodic Mississippi River flooding during the Holocene [Brown et al., 1999; Aharon, 2003].

[25] Our G. ruber $\delta^{13} \mathrm{C}$ values are consistent with open ocean $\delta^{13} \mathrm{C}_{\mathrm{DIC}}$ and with unaltered foraminiferal calcite. Comparing $\delta^{18} \mathrm{O}_{\mathrm{GOM}}$ to $\delta^{13} \mathrm{C}$ is a more direct method of isotopic tracing of flooding events (Figures $4 \mathrm{a}$ and $4 \mathrm{~b}$ ) since SST has been removed leaving only a hydrologic signal in the $\delta^{18} \mathrm{O}_{\mathrm{GOM}}$. A modest, positive relationship exists in 4 out of the 6 freshwater events, but the largest, negative excursion in $\delta^{18} \mathrm{O}_{\mathrm{GOM}}$ appears to be coincident with a positive $\delta^{13} \mathrm{C}$ excursion. If Mississippi River flooding lowered the $\delta^{13} \mathrm{C}$ of surface waters during the $8.6-8.3 \mathrm{ka}$ interval, then it may have been masked by nutrient-rich flood waters stimulating primary production and increasing the $\delta^{13} \mathrm{CDIC}$. In this study, we conclude that no consistent relationship exists between the $\delta^{18} \mathrm{O}_{\mathrm{GOM}}$ and the G. ruber $\delta^{13} \mathrm{C}$.

\section{Salinity Variability and Faunal Changes in the Early Holocene}

[26] Determining the sources of low $\delta^{18} \mathrm{O}_{\mathrm{GOM}}$ waters has implications for changes in sea surface salinity (SSS) and the volume of freshwater input. Estimated salinity is deter- mined based on a simple mixing model using modern values of $1.2 \%{ }^{18} \mathrm{O}_{\mathrm{GOM}}$ and 36 psu salinity [Fairbanks et al., 1992] and two possible freshwater end-members (0 psu salinity), $-3.5 \%$ for modern GOM precipitation [Bowen and Revenaugh, 2003] and -7\%o for modern Mississippi River system input [Ortner et al., 1995] (Figure 5). The magnitude of salinity change depends on which freshwater end-member is used.

[27] The Orca Basin modern annual salinity range is $34-$ 36 psu with increased salinity in winter months and decreased salinity in summer months [Levitus, 2003]. The estimated salinities based on the $-3.5 \%$ end-member for the early Holocene range from 38 to 30 psu (Figure 6a), which is much larger than the modern range. A salinity reduction of $\sim 5.5 \mathrm{psu}$ would be required to create the excursion from 8.6 to $8.3 \mathrm{ka}$. This is equivalent to 26 times the modern precipitation based on instrumental records [Ropelewski and Halpert, 1996] and 18 times the modern annual Mississippi River system discharge volume [Dinnel

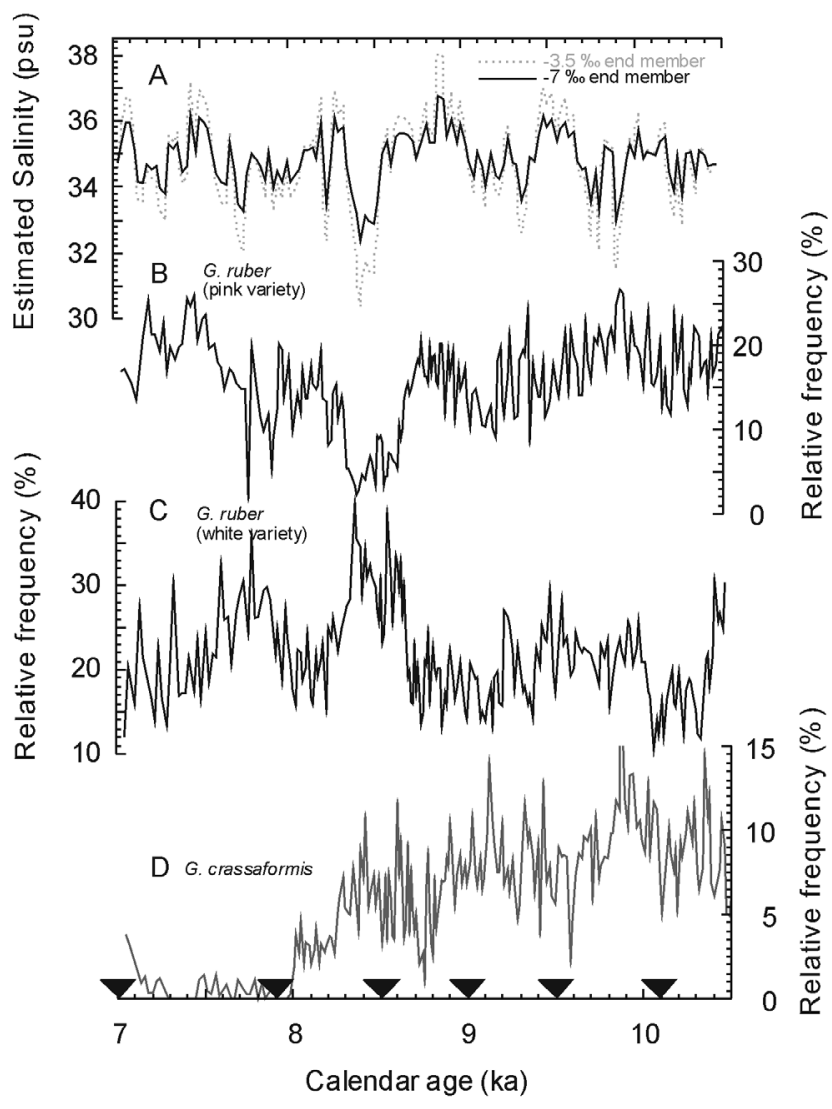

Figure 6. (a) Estimated salinities calculated from $\delta^{18} \mathrm{O}_{\mathrm{GOM}}$ based on two possible end-member compositions for freshwater input (Figure 5). (b) Relative frequency of foraminifer species G. ruber (pink variety). (c) Relative frequency of foraminifer species G. ruber (white variety). (d) Relative frequency of foraminifer species $G$. crassaformis. Inverted triangles indicate ages of six accelerator mass spectrometer ${ }^{14} \mathrm{C}$ dates for MD02-2550, calibrated to calendar years (Table 1). 


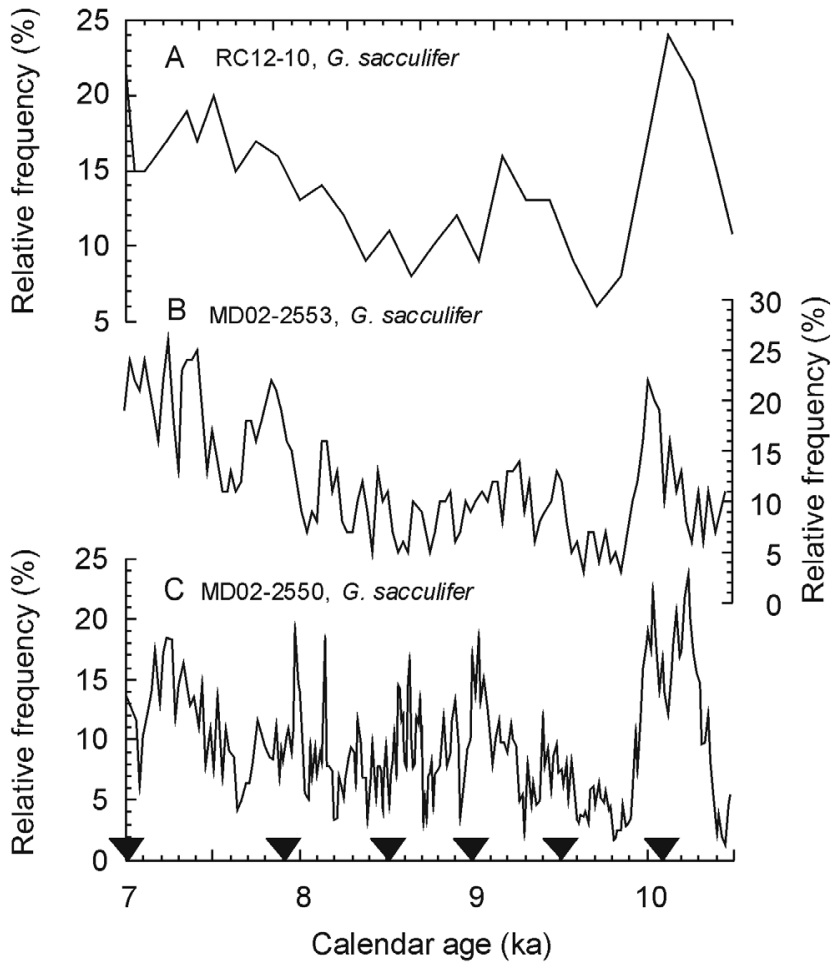

Figure 7. Relative frequency of foraminifer species $G$. sacculifer for three GOM records: (a) core RC12-10 record recovered from the Mexican Ridges region of the western GOM $\left(23.00^{\circ} \mathrm{N}, 95.53^{\circ} \mathrm{W}\right.$ at $3054 \mathrm{~m}$ water depth [Poore et al., 2003]), (b) core MD02-2553 record recovered from the Pigmy Basin $\left(27.11^{\circ} \mathrm{N}, 91.25^{\circ} \mathrm{W}\right.$ at $2259 \mathrm{~m}$ water depth [Poore et al., 2004]), and (c) core MD02-2550 record recovered from the Orca Basin (this study). Inverted triangles indicate ages of six accelerator mass spectrometer ${ }^{14} \mathrm{C}$ dates for MD02-2550, calibrated to calendar years (Table 1). RC 12-10 and MD02-2253 were also calibrated to calendar years (see text).

and Wiseman, 1986]. The salinity estimates from the modern Mississippi River system end-member (-7\%o) vary by as much as 3 psu during the early Holocene and the oscillations require as much as 10 times the modern precipitation and 4 times the modern annual Mississippi River system discharge volume. Even the $\sim 3$ psu changes estimated from the $-7 \%$ end-member seem surprisingly large, and imply a substantial contribution from Mississippi River system flooding. For comparison, using a $-15 \%$ endmember appropriate for Lake Agassiz meltwater [Remenda et al., 1994] would require only a 2 psu change in salinity.

[28] The inferred salinity changes can also be constrained by the faunal assemblage data. G. ruber is an opportunistic and euryhaline species dominating in low-salinity waters $(<34.5 \mathrm{psu})$ and high-salinity waters ( $>36 \mathrm{psu})$ [Ruddiman, 1969; Be' and Tolderlund, 1971]. Genetic differences that have been observed through molecular phylogenetic analyses between the white and pink varieties of $G$. ruber, suggest species level differences [Darling et al., 1997] and the two varieties occupy different water column depths and have different seasonal distributions in the Sargasso Sea. The white variety is present year round, whereas the pink variety is a nonwinter species [Deuser et al., 1981; Be', 1982; Deuser, 1987; Deuser and Ross, 1989; Williams et al., 1981].

[29] The relative frequency of both varieties of G. ruber develops a negative covariation by approximately $8.8 \mathrm{ka}$. The relative frequency of $G$. ruber (pink variety) begins to decrease at $8.7 \mathrm{ka}$ and declines to almost $0 \%$ by $8.4 \mathrm{ka}$. The relative frequency of $G$. ruber (white variety) begins to increase at $8.6 \mathrm{ka}$ and reaches abundances of $40 \%$ by $8.4 \mathrm{ka}$. This faunal response begins $\sim 100$ years before the largest freshwater event in salinity occurring from 8.6 to $8.3 \mathrm{ka}$. The change in the biotic community reflects an environmental change that is consistent with a broad climate anomaly preceding the 8.2 climate event known from Greenland as discussed in section 4. A similar relationship between faunal abundances and $\delta^{18} \mathrm{O}_{\mathrm{GOM}}$ is observed at $7.7 \mathrm{ka}$, which is preceded by faunal shifts at $7.8 \mathrm{ka}$.

[30] We speculate that the white variety of $G$. ruber is more opportunistic than the pink variety during the largest low-salinity events. During the last deglaciation, Orca Basin records indicate that $G$. ruber dominated during the major meltwater pulse, but the pink and white varieties were not distinguished [Kennett et al., 1985]. In addition, evidence from recent studies indicate the white variety of $G$. ruber is especially tolerant to varying salinities in the Caribbean and the Mediterranean during intervals when freshwater lenses exist over surface waters [Schmuker and Schiebel, 2002; Rohling et al., 2004].

[31] Our faunal census data also support previous work that shows the cool-water species Globorotalia crassaformis disappeared in the mid-Holocene, based on Orca Basin cores EN32-PC6 and EN32-PC4 [Kennett et al., 1985]. This species is also found to disappear from both Gyre 97-6 PC 20 from the Louisiana slope and RC 12-10 from the western GOM by the mid-Holocene [Poore et al., 2003]. Our Orca Basin record from core MD02-2550 indicates that the relative frequency of $G$. crassaformis (Figure 6d) decreases to $<2 \%$ by $8 \mathrm{ka}$.

[32] Furthermore, the relative frequency of the warmwater species $G$. sacculifer appears to be coherent in the GOM based on three records generated by two different groups (Figures $7 \mathrm{a}-7 \mathrm{c}$ ). The overall trends in amplitude and patterns are similar between core RC12-10 from the Mexican Ridges area [Poore et al., 2003], core MD022553 from Pigmy Basin [Poore et al., 2004], and core MD02-2550 from Orca Basin (this study). All three records indicate a peak of $>20 \%$ around $10 \mathrm{ka}$ and another peak of $>15 \%$ from 7.5 to $7.2 \mathrm{ka}$. Covariance at higher frequencies suggests substantial environmental variability on the centennial-scale in the GOM as well. Modern GOM $\%$ G. sacculifer do not exceed 15\%, while Caribbean waters contain $>20 \%$ [Dowsett et al., 2003]. Early Holocene values of $>15 \%$ in all three GOM records suggests episodic incursions of Caribbean waters via the Loop Current into the GOM [Poore et al., 2003]. During the early Holocene, the more northerly position of the ITCZ may have been the driving force behind this influx of warm Caribbean waters. Episodic incursions of Caribbean 
waters may have had important effects on North American continental climates.

\section{Conclusions}

[33] Paired analyses of $\delta^{18} \mathrm{O}$ and $\mathrm{Mg} / \mathrm{Ca}$ of the planktonic foraminifer G. ruber from the early Holocene from the Orca Basin indicate substantial subcentennial-scale climate variability during a time of increased seasonality in insolation. The MD02-2550 Mg/Ca-SST record contains an overall $\sim 1.5^{\circ} \mathrm{C}$ warming trend from 10.5 to $7 \mathrm{ka}$, and also reveals six high-frequency oscillations ranging from $0.5^{\circ}$ to $2^{\circ} \mathrm{C}$. A major feature of the $\mathrm{Mg} / \mathrm{Ca}-\mathrm{SST}$ record is a $\sim 1.5^{\circ} \pm 0.2^{\circ} \mathrm{C}$ warming occurring from 9.4 to $9.2 \mathrm{ka}$. The $\delta^{18} \mathrm{O}_{\mathrm{GOM}}$ record indicates hydrologic changes with amplitudes of $\sim 0.5 \%$. The $\delta^{18} \mathrm{O}_{\mathrm{GOM}}$ record also reveals considerable freshwater input from 8.6 to $8.3 \mathrm{ka}$, which appears to precede the $8.2 \mathrm{ka}$ event and may reflect a broader climate anomaly rather than the sharp cooling event documented in records of Greenland air temperatures. Faunal census data support a change in the biotic community before and throughout this $\delta^{18} \mathrm{O}_{\mathrm{GOM}}$ change. The $\mathrm{Mg} / \mathrm{Ca}-\mathrm{SST}$ record shows minimal variation during this interval. Possible causes for the hydrologic variability include large-scale changes in precipitation patterns over the GOM and episodic megaflooding from the Mississippi River system. While the variations in the $\delta^{18} \mathrm{O}_{\mathrm{GOM}}$ record do not correlate significantly with highlatitude or low-latitude climate records, the GOM records do suggest substantial hydrological and climatological changes at the subcentennial scale. Our results join a growing number of studies suggesting that the early Holocene climate in the low latitudes was highly variable. This and other regional records indicate that while solar variations play a role in subcentennial-scale climatic and hydrologic variability, other mechanisms such as atmospheric and oceanic circulation must have had an important influence on early Holocene climate.

[34] Acknowledgments. We thank the IMAGES program, Viviane Bout-Roumazeilles, Yvon Balut, and Laurent Labeyrie for a productive cruise on the R/V Marion Dufresne in 2002. We thank L. Peterson, G. Haug, and R. Poore for use of their proxy records. We also thank Ethan Goddard for support in running the ICP-OES and the SIRMS, Tom Guilderson at Lawrence Livermore National Laboratory for providing the ${ }^{14} \mathrm{C}$ dates, and Heather Hill, Sarah Judson, and Christie Stephans for lab assistance. The National Science Foundation provided funding for the study under grant OCE-0318361 to B.P.F. and T.M.Q.

\section{References}

Adkins, J. R., and D. P. Schrag (2001), Pore fluid constraints on deep ocean temperature and salinity during the last glacial maximum, Geophys. Res. Lett., 28, 771-774.

Aharon, P. (2003), Meltwater flooding events in the Gulf of Mexico revisited: Implications for rapid climate changes during the last deglaciation, Paleoceanography, 18(4), 1079, doi:10.1029/2002PA000840.

Alley, R. B., P. A. Mayewski, T. Sowers, M. Stuiver, K. C. Taylor, and P. U. Clark (1997), Holocene climatic instability: A prominent, widespread event 8200 yr ago, Geology, 25, 483-486.

Anand, P., H. Elderfield, and M. H. Conte (2003), Calibration of $\mathrm{Mg} / \mathrm{Ca}$ thermometry in planktonic foraminifera from a sediment trap time series, Paleoceanography, 18(2), 1050, doi:10.1029/2002PA000846.

Baker, R. G., and K. A. Waln (1985), Quaternary pollen records from the Great Plains and central United States, in Pollen Records of Late-Quaternary North American Sediments, edited by V. M. Bryant Jr. and R. G. Holloway, pp. 191-203, Am. Assoc. of Stratigr. Palynol. Found., Dallas Tex.

Barber, D. C., A. Dyke, C. Hillaire-Marcel, A. E. Jennings, J. T. Andrew, M. W. Kerwin, and G. Bilodeau (1999), Forcing of the cold event of 8,200 years ago by catastrophic drainage of Laurentide lakes, Nature, 400, 344-348.

Bard, E., B. Hamelin, M. Arnold, L. Montaggioni, G. Cabioch, G. Faure, and F. Rougerie (1996), Deglacial sea-level record from Tahiti corals and the timing of global meltwater discharge, Nature, 382, 241-244.

Barker, S., M. Greaves, and H. Elderfield (2003), A study of cleaning procedures used for foraminiferal $\mathrm{Mg} / \mathrm{Ca}$ paleothermometry, Geochem. Geophys. Geosyst., 4(9), 8407, doi:10.1029/2003GC000559.

Be', A. W. H. (1982), The biology of planktonic foraminifera, in Foraminifera: Notes for a Short Course, edited by T. W. Broadhead, pp. 51-92, Univ. of Tenn. Press, Knoxville.
Be', A., and W. H. Hamlin (1967), Ecology of recent planktonic foraminifera. part 3. Distribution in the North Atlantic during the summer of 1962, Micropaleontology, 6(4), 87-106.

Be', A., and D. S. Tolderlund (1971), Distribution and ecology of living planktonic foraminifera in the surface waters of the Atlantic and Indian oceans, in The Micropaleontology of Oceans, edited by B. M. Funnell and W. R. Reidel, pp. 105-149, Cambridge Univ. Press, New York

Beers, Y. (1957), Introduction to the Theory of Error, 66 pp., Addison-Wesley, Boston, Mass.

Bemis, B. E., J. H. Spero, J. Bijma, and D. W. Lea (1998), Reevaluation of the oxygen isotopic composition of planktonic foraminifera: Experimental results and revised paleotemperature equations, Paleoceanography, 13(2), $150-160$.

Bernabo, J. C., and T. Webb III (1977), Changing patterns in the Holocene pollen record of northeastern North America: A mapped summary, Quat. Res., 8, 64-96.

Bigg, G. (2003), The Oceans and Climate, pp 48-51, Cambridge Univ. Press, New York.

Bowen, G. J., and J. Revenaugh (2003), Interpolating the isotopic composition of modern meteoric precipitation, Water Resour. Res. 39(10), 1299, doi:10.1029/2003WR002086.

Brown, P., J. Kennett, and B. Lynn Ingram (1999), Marine evidence for episodic Holocene megafloods in North America and the northern Gulf of Mexico, Paleoceanography, 14(4), 498-510.

Clarke, G., D. Leverington, J. Teller, and A. Dyke (2003), Superlakes, megafloods, and abrupt climate change, Science, 301, 922-923.

Darling, K. F., C. M. Wade, D. Kroon, and A. J. Brown (1997), Planktic foraminiferal molecular evolution and their polyphyletic origins from benthic taxa, Mar. Micropaleonotol., 30, $251-266$.

Dean, W. E., R. M. Forester, and J. P. Platt Bradbury (2002), Early Holocene change in atmospheric circulation in the northern Great Plains: An upstream view of the 8.2 ka cold event, Quat Sci. Rev., 21, 1763-1775.

Deuser, W. G. (1987), Seasonal variations in isotopic composition and deep-water fluxes of the tests of perennially abundant planktonic foraminifera of the Sargasso Sea: Results from sediment-trap collections and their paleoceanographic significance, J. Foraminiferal Res., 17(1), 14-27.

Deuser, W. G., and E. H. Ross (1989), Seasonally abundant planktonic foraminifera of the Sargasso Sea: Succession, deep-water fluxes, isotopic compositions, and paleoceanographic implications, J. Foraminiferal Res., 19(4) 268-293.

Deuser, W. G., E. H. Ross, C. Hemleben, and M. Spindler (1981), Seasonal changes in species composition, numbers, mass, size, and isotopic composition of planktonic foraminifera settling into the deep Sargasso Sea, Palaeogeogr Palaeoclimatol. Palaeoecol., 33, 103-127.

Dinnel, S. P., and W. J. Wiseman Jr. (1986) Fresh water on the Louisiana and Texas shelf, Cont. Shelf Res., 6, 765-784.

Dowsett, H. J., C. A. Brunner, S. Verardo, and R. Z. Poore (2003), Gulf of Mexico planktic foraminifer core-top calibration set: Raw data, U.S. Geol. Surv. Open File Rep. 03-08, 15 pp.

Fairbanks, R. G. (1989), A 17,000-year glacioeustatic sea level record: Influence of glacial melting rates on the Younger Dryas event and deep-ocean circulation, Nature, 342, 637-642.

Fairbanks, R. G., C. D. Charles, and J. D. Wright (1992), Origin of global meltwater pulses, in Radiocarbon After Four Decades, edited by R. E. Taylor et al., pp. 473-500, Springer, New York.

Fisher, T. G. (2003), Chronology of glacial Lake Agassiz meltwater routed to the Gulf of Mexico, Quat. Res., 59, 271-276.

Flower, B. P., and J. P. Kennett (1990), The Younger Dryas cool episode in the Gulf of Mexico, Paleoceanography, 5, 949-961.

Flower, B. P., and J. P. Kennett (1995), Biotic responses to temperature and salinity changes 
during the last deglaciation, Gulf of Mexico, in Effects of Past Global Change on Life, edited by S. M. Stanley, pp. 209-220, Natl. Acad. Press, Washington, D. C.

Grootes, P. M., M. Stuiver, J. W. C. White, S. Johnsen, and J. Jouzel (1993), Comparison of oxygen-isotope records from the GISP2 and GRIP Greenland ice cores, Nature, 366, $552-$ 554

Haug, G. H., K. A. Hughen, D. M. Sigman, L. C. Peterson, and U. Rohl (2001), Southward migration of the Intertropical Convergence Zone through the Holocene, Science, 293, $1304-1308$

Hemleben, C., M. Spindler, and O. R. Anderson (1989), Modern Planktonic Foraminifera, 363 pp., Springer, New York.

Hodell, D. A., J. H. Curtis, G. A. Jones, A. HigueraGundy, M. Brenner, M. W. Binford, and K. T. Dorsey (1991), Reconstruction of Caribbean climate change over the past 10,500 years, Nature, 352, 790-793.

Hughen, K. A., J. T. Overpeck, L. C. Peterson, and S. Trumbore (1996), Rapid climate change in the tropical Atlantic region during the last deglaciation, Nature, 375, 391-394.

Kennett, J. P., K. Elmstrom, and N. Penrose (1985), The last deglacial in Orca Basin, Gulf of Mexico high-resolution planktonic foraminiferal changes, Palaeogeogr. Palaeoclimatol. Palaeoecol., 50, 189-216.

Klitgaard-Kristensen, D., H. P. Sejurp, H. Haflidason, S. Johnsen, and M. Spurk (1998), A regional 8200 cal. yr. cooling event in northwest Europe, induced by the final stages of the Laurentide Ice Sheet deglaciation?, J. Quat. Sci., 13, $165-169$

Knox, J. C. (2000), Sensitivity of modern and Holocene floods to climate change, Quat. Sci. Rev, 19, 439-457.

Kutzbach, J. E., and R. G. Gallimore (1988), Sensitivity of a coupled atmosphere/mixed layer ocean model to changes in orbital forcing at 9000 years B.P., J. Geophys. Res., 93, 803821.

Lachniet, M. S., Y. Asmerom, S. J. Burns, W. P. Patterson, V. J. Polyak, and G. O. Seltzer (2004), Tropical response to the 8200 yr B.P. cold event? Speleothem isotopes indicate a weakened early Holocene monsoon in Costa Rica, Geology, 32, 957-960.

Laskar, J. (1990), The chaotic motion of the solar system-A numerical estimate of the size of the chaotic zones, Icarus, 88(2), 266-291.

Lea, D. W., D. K. Pak, L. C. Peterson, and K. A. Hughen (2003), Synchroneity of tropical and high-latitude Atlantic temperatures over the last glacial termination, Science, 301(5638), $1361-1364$

Leventer, A., D. F. William, and J. P. Kennett (1983), Relationships between anoxia, glacial meltwater and microfossil preservation in the Orca Basin, Gulf of Mexico, Mar. Geol., 53, $23-40$.

Levitus, S. (2003), National Oceanographic Data Center World Ocean Atlas 1994, at http:// www.cdc.noaa.gov/, Clim. Data Cent., Boulder, Colo.

LoDico, J. M. (2006), Sub-centennial scale climatic and hydrologic variability in the Gulf of Mexico during the early Holocene, Masters thesis, Univ. of South Florida, St. Petersburg.

Metcalfe, S. E., S. L. O'Hara, M. Caballero, and S. J. Davies (2000), Records of late Pleistocene-Holocene climatic change in MexicoA review, Quat. Sci. Rev., 19, 699-721.
Mitchell, J. F. B., N. S. Grahame, and K. J. Needham (1988), Climate simulations for 9000 years before present: Seasonal variations and effect of the Laurentide Ice Sheet, J. Geophys. Res., 93, 8283-8303.

Moore, T. C., J. C. G. Walker, D. K. Rea, C. F. M. Lewis, L. C. K. Shane, and A. J. Smith (2000), Younger Dryas interval and outflow from the Laurentide Ice Sheet, Paleoceanography, 15(1), 4-18.

Nordt, L. C., T. W. Boutton, C. T. Hallmark, and M. R. Waters (1994), The late Quaternary vegetation and climatic changes in central Texas based on the isotopic composition of organic carbon, Quat. Res., 41, 109-120.

Ortner, P. B., T. N. Lee, P. J. Milne, R. G. Zika, M. E. Clarke, G. P. Podesta, P. K. Swart, P. A. Tester, L. P. Atkinson, and W. R. Johnson (1995), Mississippi River flood waters that reached the Gulf Stream, J. Geophys. Res. $100,595-601$

Peterson, L. C., G. H. Haug, K. A. Hughen, and U. Röhl (2000), Rapid changes in the hydrologic cycle of the tropical Atlantic during the last glacial, Science, 290, 1947-1951.

Poore, R. Z., H. J. Dowsett, S. Verardo, and T. M. Quinn (2003), Millennial- to century-scale variability in Gulf of Mexico Holocene climate records, Paleoceanography, 18(2), 1048 , doi:10.1029/2002PA000868

Poore, R. Z., T. M. Quinn, and S. Verardo (2004), Century-scale movement of the Atlantic Intertropical Convergence Zone linked to solar variability, Geophys. Res. Lett., 31, L12214, doi:10.1029/2004GL019940.

Reimer, R. W., S. Remmele, J. R. Southon, M. Stuiver, S. Talamo, F. W. Taylor, J. van der Plicht, and C. E. Weyhenmeyer (2004), IntCal04 terrestrial radiocarbon age calibration, 26-0 cal kyr BP, Radiocarbon, 46, $1029-1058$

Remenda, V. H., J. A. Cherry, and T. W. D. Edwards (1994), Isotopic composition of old groundwater from Lake Agassiz: Implications for late Pleistocene climate, Science, 266, 1975-1978.

Rohling, E. J., and H. Pälike (2005), Centennialscale climate cooling with a sudden cold event around 8,200 years ago, Nature, 434, 975-979.

Rohling, E. J., et al. (2004), Reconstructing past planktonic foraminiferal habitats using stable isotope data: A case history for Mediterranean sapropel S5, Mar. Micropaleonotol., 50, 89 123.

Ropelewski, C. F., and M. S. Halpert (1996), Quantifying southern oscillation-precipitation relationships, J. Clim., 9(5), 1043-1059, doi:10.1175/1520-0442(1996)009<1043 QSOPR $>2.0 . \mathrm{CO} ; 2$.

Ruddiman, W. F. (1969), Planktonic foraminifer of the subtropical North Atlantic gyre, Ph.D. thesis, Columbia Univ., New York, N. Y.

Ruddiman, W. F. (2001), Earth's Climate Past and Future, 318 pp., W. H. Freeman, New York.

Ruhlemann, C., S. Mulitza, P. J. Muller, G. Wefer, and R. Zahn (1999), Warming of the tropical Atlantic Ocean and slowdown of thermohaline circulation during the last deglaciation, Nature, $402,511-514$

Schmidt, M. W., H. J. Spero, and D. H. Lea (2004), Links between salinity variation in the Caribbean and North Atlantic thermohaline circulation, Nature, 428, 160-163.

Schmuker, B., and R. Schiebel (2002), Planktic foraminifers and hydrography of the eastern and northern Caribbean Sea, Mar. Micropaleonotol., 46, 387-403.

Schrag, D. P. (1999), Rapid analysis of highprecision $\mathrm{Sr} / \mathrm{Ca}$ ratios in corals and othe marine carbonates, Paleoceanography, 14(2), 97-102.

Spero, H. J., K. M. Mielke, E. M. Kalve, D. W. Lea, and D. K. Pak (2003), Multispecies approach to reconstructing eastern equatoria Pacific thermocline hydrography during the past 360 kyr, Paleoceanography, 18(1), 1022 , doi:10.1029/2002PA000814.

Stuiver, M., P. J. Reimer, E. Bard, J. W. Beck, G. S. Burr, K. A. Hughen, B. Kromer, F. G. McCormac, J. Van Der Plicht, and M. Spurk (1998), INTCAL98 radiocarbon age calibration 24,000-0 cal BP, Radiocarbon, 40, $1041-1083$.

Tan, F. C. (1989), Stable carbon isotopes in dissolved inorganic carbon in marine and estuarine environments, in Handbook of Environmental Geochemistry, vol. 3A, edited by P. Fritz and J. C. Fontes, pp. 171-190, Elsevier, New York.

Teller, J. T., D. W. Leverington, and J. D. Mann (2002), Freshwater outbursts to the oceans from glacial Lake Agassiz and their role in climate change during the last deglaciation, Quat. Sci. Rev., 21, 879-887.

Thunell, R., E. Tappa, C. Pride, and E. Kincaid (1999), Sea-surface temperature anomalies associated with the 1997-1998 El Niño recorded in the oxygen isotope composition of planktonic foraminifera, Geology, 27, $843-846$.

Tinner, W., and A. Lotter (2001), Central European vegetation response to abrupt climate change at $8.2 \mathrm{ka}$, Geology, 29, 551-554. von Grafenstein, U., H. Erlenkeuser, J. Muller, J. Jouzel, and S. Johnsen (1998), The cold event 8200 years ago documented in oxygen isotope records of precipitation in Europe and Greenland, Clim. Dyn., 14, 73-81.

Wang, C., and C. B. Enfield (2001), The tropical Western Hemisphere Warm Pool, Geophys. Res. Lett., 28, 1635-1638.

Webb, R. S., K. H. Anderson, and T. Webb III (1993), Pollen response-surface estimates of late Quaternary changes in moisture balance of the northeastern United States, Quat. Res., $40,213-227$.

Webb, T., III, E. J. Cushing, and H. E. Wright Jr (1983), Holocene changes in vegetation of the Midwest, in Late-Quaternary Environments of the United States, vol. 2, edited by H. E. Wright Jr., pp. 142-165, Univ. of Minn. Press, Minneapolis.

Williams, D. F., W. H. Allan, and R. G. Fairbanks (1981), Seasonal stable isotopic variations in living planktonic foraminifera from Bermuda plankton tows, Palaeogeogr. Palaeoclimatol. Palaeoecol., 33, 71-102.

Zaric, S., B. Donner, G. Fischer, S. Mulitza, and G. Wefer (2005), Sensitivity of planktonic foraminifera to sea surface temperature and export production as derived from sediment trap data, Mar. Micropaleonotol., 55, 75-105.

B. P. Flower, J. M. LoDico, and T. M. Quinn, College of Marine Science, University of South Florida, St. Petersburg, FL 33701, USA. (jlodico@ marine.usf.edu) 